\title{
1. Extractive and power-preserving political corruption
}

\section{Inge Amundsen}

\section{POLITICAL CORRUPTION AND POLITICAL WILL}

Political corruption is different from administrative/bureaucratic corruption. A corrupt president, government minister or ruling party is a different sort of problem than is, for example, a teacher or nurse taking bribes to offer services. The problem with political corruption is that it serves a function beyond greed and personal enrichment - it may keep the regime together and afloat. Political corruption not only gives the incentives for controlling the state, it is a means to maintain control of the state. The rulers will have no political will to eradicate political corruption as it gives them wealth and power, whereas bureaucratic corruption can be eradicated if the rulers so desire.

The distinction between political and bureaucratic corruption is important for the analysis and measurement of corruption, and the distinction is essential in order to make meaningful anti-corruption interventions. Nevertheless, even the most respected scholarly literature on corruption frequently undercommunicates, misunderstands or ignores the distinction, to the detriment of a sound understanding and analysis of the problem, and to the impairment of anti-corruption efforts.

Some of the classic and authoritative scholarly work on corruption, such as Heidenheimer and Johnston (2002) and Heywood (2015), make no clear distinction between the two forms of corruption. For instance, in their book Political Corruption: Concepts and Contexts, Heidenheimer and Johnston (2002) are using the term 'political corruption' synonymously to the term 'corruption', although with a political context in mind and with the 'aim of 
bringing the term into the political realm', but without explicitly ruling out the non-political forms of corruption. In the introduction, for instance, the editors discuss corruption as 'political and bureaucratic behaviour' (ibid.: 12), which makes it clear they subsume bureaucratic corruption under the term 'political corruption'.

Likewise, Heywood in his Routledge Handbook of Political Corruption (2015) fails to make the distinction. He states that political corruption 'is now as likely to take the form of conflicts of interests, abuse of office, lobbying [...] and inappropriate use of public information as it is to take more traditional forms such as bribery and embezzlement' (ibid.: 4). This is largely but not exclusively mechanisms found on the 'political' side, but Heywood offers no specific definition of political corruption, and throughout the book political corruption is understood as corruption anywhere in the public sector.

Some researchers use the term 'political corruption' very narrowly, for instance as corruption in elections (only) or as political donations (only), and others use it to attract attention. An example of a dubious and sensationalist use of the concept of 'political corruption' is Hjellum (2007). In his book Political Corruption as a Democratic Problem he makes no analytical distinction between political and bureaucratic/administrative corruption, and he mixes the terms throughout even when his text is almost exclusively on administrative corruption. At the same time, the book cover depicts senior politicians in Norway.

The biggest and most influential of the world's anti-corruption non-government organisations (NGOs), Transparency International (TI), makes the distinction in theory, but not in practice. TI's Global Corruption Report, special issue 2004 on political corruption, defines political corruption as 'the abuse of entrusted power by political leaders for private gain' (TI 2004: 1). ${ }^{1}$ It specifies political corruption as corruption in political finance, vote-buying, sale of appointments, abuse of state resources, trading in influence and the 
granting of favours. Furthermore, it separates political from bureaucratic corruption by stating that political corruption is 'distinct from petty or bureaucratic corruption in so far as it is perpetrated by political leaders or elected officials who have been vested with public authority and who bear the responsibility of representing the public interest' (ibid.: 11).

This clarification has, however, had few consequences for TI's further work on corruption. Most glaring is TI's annually updated Corruption Perceptions Index (CPI), which lacks the distinction entirely and is lumping together very different social phenomena under the one heading. The index is measuring "public sector corruption', explicitly understood as political and bureaucratic corruption combined. A TI background paper on the CPI methodology states: 'As has been emphasized in the background documents of previous years, the sources do not distinguish between administrative and political corruption' (Lambsdorff 2007: 5).

Many researchers use 'corruption' and 'political corruption' almost interchangeably (Heywood 2015: 7), applying the term 'political' to denote both political and bureaucratic corruption. One example is Hessami (2014: 373), who talks about political corruption as involving 'the political and bureaucratic decision makers'. Others are using the term 'public sector corruption' (Johnston 2011) to refer to both political and bureaucratic corruption. Yet other researchers use concepts like 'government' (Frederickson 2015), 'executive' (V-Dem Institute 2016) or 'elite' corruption (Tangri and Mwenda 2013) to denote high-level political corruption.

A few researchers have, however, made the distinction explicit, and even applied the distinction in their research. Among the few are Loftis, who uses a measure that 'differentiates political corruption from corruption at lower levels of government' (2014: 728) in a dataset on policy-making in ten former communist European Union member states. Another example is Villoria et al., who argue that (most) studies 'have not examined administrative corruption separately from political corruption'. They highlight their understanding of the two forms of corruption in stating that 'grand or political corruption refers to corrupt actions by elected politicians, and petty or administrative corruption as involving public sector employees or bureaucrats' (2013: 85-6), and they are applying this distinction in their survey on popular perceptions of corruption and politics in Spain. 
There is a need to make the distinction clear and explicit. This is what we present in the following: a conceptual and theoretic distinction between political corruption and bureaucratic corruption. Despite the blurred boundaries and many overlaps between politics and administration (in theory as well as in practice), we offer a relatively clear-cut distinction.

After this exercise, we are outlining two basic and often interrelated forms of political corruption, namely 'extractive' and 'power-preserving' political corruption. The short version is that both forms of corruption are for the purpose of gains in wealth, status and power, but extractive political corruption is mainly for the purpose of wealth and status. It is extractive when political power-holders are enriching themselves, their family and relatives, their political friends and allies, and their ruling parties and governments. It is a form of abuse of power 'to get the money in'. It includes practices such as embezzlement, economic crime, 'privatisations' and crony capitalism (favouring their own businesses), and, most importantly, bribe taking in public procurement.

Power-preserving political corruption, on the other hand, is mainly for maintaining and/or strengthening political powerholders' hold on power. It is when they are using (reinvesting) their corruptly acquired means and other resources in corrupt ways to safeguard and perpetuate their power position. It is one of many forms of power abuse utilised to maintain the grip on power, and it often comes in addition to (or prior to) the use of violence, intimidation, threats and manipulation of elections. Powerpreserving political corruption includes practices such as buying friends (favouritism, co-optations, clientelism and nepotism), buying support from businesses (by favouring the businesses of political supporters), buying institutions of oversight and control (through appointments and inducements), the use of state resources to win elections, and buying judicial impunity. We are giving a number of examples to illustrate these mechanisms.

Finally, we are looking at the implications of specifying and distinguishing between political corruption and bureaucratic/ administrative corruption. The distinction has wide-ranging consequences for research on corruption, because these qualitatively distinct social phenomena require different analytical frameworks, conceptual models, and investigation and data collection methods. 
More importantly, they require different approaches to anticorruption. Bureaucratic corruption can fruitfully be understood within the principal-agent framework, and measures to stem bureaucratic corruption can be implemented in terms of monitoring, oversight, sanctions and punishment. These can be very effective in curbing corruption if the principals, the government, have the political will to do so. Political corruption cannot, however, as political corruption destroys the political will of politicians to curb corruption. Corrupt leaders will not restrict their enrichment and risk their hold on power. To stem political corruption, we need a better understanding of the political economy and political incentives in a given situation, and politically informed action.

\section{POLITICAL CORRUPTION DEFINED}

'Corruption' is a concept much used and misused in social sciences as well as in the general parlance; it usually encompasses a large number of illegal and/or deplorable social activities and a number of human actions that someone might consider detrimental or unacceptable. Without a proper definition, the concept is too broad for analytical purposes.

According to the World Bank's thumb-rule definition, corruption is 'abuse of public power for private benefit' (World Bank 1997: 8). There are also a number of other and more elaborate definitions of corruption, such as the classic definitions that "corruption is behaviour of public officials which deviates from accepted norms in order to serve private ends' (Huntington 1968: 59), and that it is 'behaviour that deviates from the formal duties of a public role (elective or appointive) because of private-regarding (personal, close family, private clique) wealth or status gains; or violates rules against the exercise of certain types of private regarding influence' (Nye 1967: 419).

The common denominator is that there is always a public servant or politician involved - those holding public power. They are making a 'private benefit' of that; they are pocketing something, big or small. ${ }^{2}$

2 That is, some, like TI, will insist there is also private-to-private corruption, not involving public officials or politicians. This is reflected in their definition of 
On the other side of the corrupt act is the non-public actor, either a private business (a company, contractor), a private citizen (as user of public services, taxpayer and so on), a civil society organisation, or any other non-public entity. These are the 'corruptors' seeking some return or benefit from corrupting a public official. Thus, corruption is a relationship between at least two actors, from which both parties will gain something. ${ }^{3}$

Who will gain more, at the end of the day, the corrupter or the corrupted, is an empirical question. It is not given a priori who will be the winner, but information on who took the initiative to establish the corrupt deal in the first place is usually an indicator as to who believes he or she will benefit more.

Political corruption takes place at the highest levels of the political system, and involves political decision makers: politicians, government ministers, senior civil servants, and other elected, nominated and (self-) appointed senior public-office holders. Political corruption is when these officials, who make the laws (the 'rules of the game'), are abusing their public power for private benefit.

By political decision makers we mean presidents and heads of state (including vice-presidents and core personnel of the president's office and inner cabinet), heads of government (prime ministers) and government/cabinet ministers (including viceministers, their advisors and the like). We also include ruling party officials (party presidents and general secretaries, for instance), top

corruption as 'abuse of entrusted power for private gain' (TI website, https://www. transparency.org/whoweare/organisation/faqs_on_corruption\#defineCorruption, accessed 17 August 2018, my emphasis), as for instance involving a private company employee and a customer. In my opinion, this relationship should be excluded from the debate on corruption. Firstly, because 'private-to-private' corruption is largely self-regulatory (the employee will be punished swiftly and harshly when detected). Secondly, 'private-to-private' corruption is less damaging. It can harm the profits and reputation of a firm and increase the overall acceptance of corruption in society, but it will not directly affect public services or the quality of politics. Besides, for our purpose (analysing political corruption), a definition that necessarily includes the corrupted public side is preferable.

3 The exception is embezzlement, where the public officials steal from public coffers, alone with no corrupters. It is still 'abuse of public power for private benefit'. 
military, police and security officers, and high-level bureaucrats. ${ }^{4}$ We also include parliamentarians of the ruling party or party coalition, and a number of people nominated by the president: supreme and military court judges, heads of government special institutions (such as auditors, public prosecutors, ombudsmen, tax commissioners, election commissioners, national bank directors) and heads of public companies. ${ }^{5}$ Other researchers have been using related terms such as 'the ruling elite' and 'the powerful few'.

Some researchers regard political corruption to be the same as 'grand corruption', for example Moody-Stuart (1997) when he says that grand corruption 'occurs at the highest levels of government and involves major government projects and programs'. However, even when political corruption can be grand in scale, it is not necessarily so. To buy a vote in Kenya, for instance, will cost no more than one US dollar. It is a question of level, not of scale.

In contrast to political corruption, bureaucratic or administrative corruption takes place at the implementation end of politics, and mainly in public service delivery such as education, health, water and utilities. Bureaucratic corruption is sometimes called 'petty', 'everyday', 'routine' and 'street-level' corruption, ${ }^{6}$ but these concepts give some incorrect connotations as bureaucratic corruption can be huge in economic terms and widespread in social terms, and it can form the basis of an upward spiral of extraction.

4 The British comedy series Yes, Minister should illustrate why the top-level bureaucrats are included.

5 In many presidential systems, in particular in the developing world, the president of the Republic has wide authorities to nominate (and sack) people. As an illustration, the president of Angola is Head of State, Head of Government, Commander-in-Chief of the Armed Forces, and president of the ruling party, and he appoints (and can remove) the vice-president and the Council of Ministers (cabinet), the prime minister, line ministers and vice-ministers, the Attorney General, the Governor of the Central Bank, generals and other commanders of the armed forces, police, and security services, members of the judiciary including the Supreme and Military Court, and all provincial governors (according to Constituição da República de Angola, January 2010; articles 119, 120, 122, 123 and 128).

6 The TI Glossary (ibid.) defines 'petty corruption' as the 'everyday abuse of entrusted power by low- and mid-level public officials in their interaction with ordinary citizens, who often are trying to access basic goods or services in places like hospitals, schools, police departments and other agencies'. Likewise, 'facilitating payments' have been defined as 'small sums that are paid with the intention of motivating low-level officials to expedite routine procedures' (Argandoña 2017: 71). 
Bureaucratic corruption can be distinguished from political corruption in the same way as politics can be distinguished from public administration. In the textbook understanding, politics or policy-making is the 'distribution of favours and burdens in society' or 'the authoritative allocation of values for a society' (Easton 1965: 50), whereas public administration is concerned with the 'implementation of government policy' (Encyclopædia Britannica). This distinction seems intuitive and uncomplicated, until one takes a closer look.

As politicians lack absolute control, leaving quite a lot of discretionary decision-making to the bureaucrats, and the perennial principal-agent problem, policy-making and implementation cannot always be separated. Often, politicians will interfere in the implementation of policies and service delivery, and bureaucrats will interfere in policy-making. Likewise, politicians can instruct their bureaucrats to do the dirty jobs for them (to extract and protect), sometimes they will do it out of loyalty or fear. A permanent secretary can 'find' money for the minister's wife's shopping spree.

Besides, the two levels are dependent upon each other. The politicians 'define the essential lines of the public administration' and they influence 'both the risks and opportunities of bureaucratic corruption' (della Porta and Vannucci 1999: 131). At the same time, politicians are dependent on public administrations for the implementation of policies, including the corrupt ones. It has even been argued that bureaucrats can 'denounce the illegitimate actions of politicians, or they can refuse to carry out the measures' (ibid.). (This opens up a possible inroad to anti-corruption: bureaucrats can to some extent restrict the corrupt behaviour of politicians, if they want to - the same was as politicians can restrict the corrupt behaviour of bureaucrats, if they want to).

Political and bureaucratic corruption also tend to be mutually reinforcing. Andvig et al. (2001) assume that "political corruption is usually supported by widespread bureaucratic or petty corruption, in a pyramid of upward extraction. And corruption in high places is contagious to lower level officials, as these will follow the predatory examples of, or even take instruction from, their principals' (2001: 11).

Thus, it seems obvious that political and bureaucratic corruption can go together, in a mutually reinforcing evil circle. But it is not 
necessarily so. Political corruption can take place in a polity with little or no bureaucratic corruption. France can serve as an example, with its Napoleonic civil code, bureaucratic ésprit de corps and stiff penalties and social stigma on bureaucratic misbehaviour; and with its Ile de France (see below) and ELF Aquitaine corruption scandals that reached the top of French politics. ${ }^{7}$

Likewise, bureaucratic corruption can take place in systems with little or no political corruption. Examples are few, however, and tend to disappear after a while as new clean governments (typically elected on an anti-corruption ticket) tend to be caught up quickly (some say 100 days) by the corruption opportunities and pressures. ${ }^{8}$

Despite these mutual dependencies that create ambiguities in the distinction between political and bureaucratic corruption, we still believe it is meaningful and fruitful to argue for a separation. We base this on the argument that political corruption involves those entrusted with the power to formulate the rules and the regulations, whereas bureaucratic corruption involves those with the delegated authority to implement political decisions and provide public services. In other words, political corruption is when the power holders and politicians who make the laws (the 'rules of the game') are abusing their public power for private benefit.

Furthermore, political and bureaucratic behaviour (and the appurtenant corruption) is regulated differently. Whereas political behaviour is regulated by the separation of powers, institutional checks and balances, constitutions, established practice and - last but not least - by elections and democratic procedures, bureaucratic behaviour is regulated by political guidance, civil service laws and regulations, codes of ethics, and so on. The legal sanctions on political and bureaucratic corruption are also often defined differently; civil servants are punished less hard for misbehaviour than are elected politicians.

\footnotetext{
7 According to the journalist Nick Cohen, the Elf scandal in 1994 in France was "the biggest fraud inquiry in Europe since the Second World War [...] Elf became a private bank for executives who spent $£ 200$ million on political favours, mistresses, jewellery, fine art, villas and apartments' (Cohen 2007).

8 The 'rainbow coalition' government in Kenya (2002-5) is one example of a 'zero-tolerance government' that quickly ran into problems with government procurement including the new police telecommunications and new passport system (dubbed the Anglo-Leasing scandal).
} 
Although the distinction between political and administrative corruption is not cut in stone - there are grey areas of bureaucratic discretionary decision-making, unclear areas of responsibility, and the perennial principal-agent problem - the distinction is very productive in analytic and practical terms, as we will see later.

\section{EXTRACTION AND POWER PRESERVATION}

Going from who (politicians, government ministers, senior civil servants and other elected, nominated and (self-) appointed senior public office holders) to why and how, we can also identify the functions of political corruption. We will argue that political corruption can and should be divided into two basic, critical and related processes.

The first process we name extractive political corruption. This is when political power holders are enriching themselves by abusing their hold on power to extract from public and private resources. The second we name power-preserving political corruption, which is when political power holders are using the corruptly acquired means, as well as other resources, in corrupt ways to maintain and/or strengthen their hold on power.

The consequences of these two forms of political corruption are serious. In economic terms, the consequences are devastating for investments: it impedes normal economic activities, it exacerbates economic inequalities and inefficiencies, and when systemic it jeopardises countries' economic development potential. In political terms, political corruption annihilates the political will of politicians to address the corruption problem, it erodes trust and legitimacy in government and politics in general, it makes political decisions non-transparent, it undermines political accountability mechanisms and it often leads to authoritarianism.

Alas, political corruption is often the main incentive for holding on to political power at the same time as political corruption provides the means to hold on to power. An evil circle of extraction and reinvestment in power occurs when these two forms of political corruption feed into each other. When political corruption produces the incentives for controlling the state, at the same time as it produces the means to retain control of the state, we have a 
situation that has been called a kleptocratic form of government, ${ }^{9}$ which is particularly hard to democratise.

\section{EXTRACTIVE POLITICAL CORRUPTION}

Extractive political corruption is when political leaders use their political power (formal and informal position, information and influence) to extract resources from the public and from the private sector (as in from the nation's wealth), for individual and/or group enrichment, in an illegal and/or immoral way.

Extractive political corruption is sometimes called 'graft', and takes many forms. Andvig et al. (2001: 8-10) made a typology of the forms of corruption one can expect to find in a given administration. Below, we list the commonly used forms of corrupt extraction: bribery, embezzlement, fraud and extortion.

\section{Bribery}

Bribery is the classic form of corruption: it is any amount of money or favours in kind paid to a political power holder (in person, or to their family members, organisation or the ruling party). It is offered and paid by national and international companies to obtain rentseeking opportunities: access to natural resources, concessions, state contracts in civil engineering projects, construction works, defence supplies, and so on. It is high-level bribery when politicians, against 'a fee', alter the rules and regulations and mediate the market to create market protection, provide state loans and guarantees, make tax 'havens' and 'honeymoons', reduce environmental and worker standards, and so on, for the benefit of private firms.

However, with more international and national attention to and knowledge of the problem of bribery, and with strengthened national and international legislation, the classic forms of bribe taking have shifted to some less visible and more 'legal' forms of

9 Kleptocracy is, literally, rule by thieves, and focuses on the corrupt state officials as the main culprits. In contrast, state capture is a type of systemic political corruption in which private interests significantly influence a state's decision-making processes to their own advantage, with a focus on the corrupting private side as the main culprits. 
corruption, fraud in particular. It has also shifted to military procurement, businesses owned and run by military and security forces, and large infrastructure projects, which are increasingly exposed to this form of corruption, and particularly hard to control because of the involvement of senior politicians, national interests, and secrecy. ${ }^{10}$

One example of top-level bribery is the 'arms deal' scandal in South Africa, where millions of rand were channelled from arms dealers through local companies and brokers to politically connected figures (Nattrass 2014: 72). Sweetheart deals proliferated in the arms procurement programme, allegedly giving friends of senior politicians (including President Thabo Mbeki's brother) a share of the defence pie under the rubric of 'black empowerment' (TI 2004: 62, see also Chapter 8 on South Africa in this volume).

Another example is the scandal that erupted in October 2004 when the former president of Costa Rica, Miguel Angel Rodríguez, was forced to resign as Secretary-General of the Organization of American States. According to TI, 'he stepped down after allegations implicated him in a bribery scheme involving the French telecommunications company, Alcatel. In mid-2004, details emerged that Alcatel had been awarded a contract to improve the country's cellular phone system allegedly after its officials successfully bribed José Antonio Lobo, Rodríguez's protégé and a former director of the state electrical company, with a USD 2.4 million "prize". Lobo said he had been "advised" to accept the sum by Rodríguez, who is reported to have demanded 60 per cent of it. Digging deeper into Alcatel's dealings, allegations emerged that it had attempted to influence previous and current Costa Rican politicians as well' (TI 2006: 146-7).

10 In Turkey, for instance, despite losing much of its political power recently, the military is a substantial economic actor with a stake in 60 companies in sectors ranging from cars to chocolate bars. There are two unique channels through which the military is directly involved in market activities: two state investment funds (the Armed Forces Trust and the Pension Fund (OYAK)), and the Foundation for Strengthening the Turkish Armed Forces (TSKGV) (Demir 2010: 4). In Angola, the ruling party MPLA owns a company called GEFI (Sociedade de Gestão e Participações Financeiras), which has a business portfolio that includes participation in 64 companies operating in the sectors that include hotels, industry, banking, fisheries, aviation, media, construction and real estate (Amundsen 2014: 176). In Rwanda, the situation is the same with party-owned enterprises that get preferential treatment by the government, as analysed by Booth and Golooba-Mutebi (2012). 
A third example is the Ile de France trials of 2005, in which an extensive system of corruption in procurement contracts for the renovation of high schools was revealed. The case involved 47 defendants, charged with collusion, concealing corruption and influence peddling. The accusations centred on allegations that companies paid major political parties to win contracts to renovate schools around Paris. The defendants include a former cooperation minister, an ex-president of the Ile de France regional council and a former labour minister, as well as the former treasurers of three political parties (TI 2006: 158-9).

\section{Embezzlement}

Embezzlement is the theft or misappropriation of state assets (funds, property and services) from the public institution where someone has a position of authority and trust; it is theft of resources they are supposed to administer on behalf of the public. Embezzlement can occur regardless of whether the offender keeps the personal property or transfers it to a third party. Often the trusted individual is embezzling only a small proportion of the total of the funds or resources they receive or control, in an attempt to minimise the risk of the detection of the misallocation.

In embezzlement, there is often an element of fraud (see below). While legally not considered as corruption in most legal systems (but as a separate crime, along with fraud), embezzlement is nevertheless covered in the definition of corruption as abuse of public power for private benefit.

One recent, well-known high-level embezzlement case is Malaysia's former prime minister Najib Razak who was accused in 2015 of channelling to his personal bank accounts over 2.67 billion ringgit (nearly 700 million US dollars) from the 1Malaysia Development Berhad (1MDB), a government-run strategic development company. This led to the prime minister being ousted in the May 2018 election, and for his party to lose power for the first time since 1957 (Fraud Magazine 2018, The Guardian 2015).

Another prominent example is the Baikonur scandal in Kazakhstan. This was embezzlement of funds paid by Russia for renting the Baikonur space facility in the Kazakh steppes. It involved the head of the presidential administration, Tasmagambetov, who was prime minister when the deal was struck, and had signed the 
agreement and nominated the preferred operator. Moreover, Ermegiyaev, son of the vice-president of the ruling party, had supervised the tender commission, and Alexander Pavlov, the deputy prime minister, had monitored the execution of the deal (TI 2006:185-6).

\section{Fraud}

Fraud is the use of false representations, manipulation or distortion of information, facts and expertise to secure an unfair or unlawful gain. Fraud is a method of extractive political corruption when power holders take a share for 'closing their eyes' on economic crimes and, more seriously, when they have an active role in it.

Fraud has an element of cheating and intentional deception (thus including 'imposter scams' and 'money-making scams'), and in most jurisdictions the requisite element of fraud is the intentional misrepresentation or concealment of an important fact. Self-interest is often one of these hidden facts, leading to situations of concealed conflicts of interest.

One example of high-level political fraud is when politicians enter businesses themselves and create companies that get politically mediated preferential treatment, contracts, subventions, tax exemptions and monopolies. The self-interest is concealed. It is fraud when politicians render favours to the companies of their family, political supporters, the ruling party and the military, concealing the self-interest and interests of their political supporters and backers. It is high-level fraud also when 'privatisation' processes create politically connected billionaires, in line with what happened in Russia after the fall of the Soviet Union.

Another example of high-level fraud, as it falls under the definition of 'abuse of public power for private benefit' (although it is perfectly legal in the countries concerned), is the establishment of anonymous companies by regime insiders. These so-called 'dead meat' companies (oil companies in particular) are shell companies owned by people such as previous and current ministers and state oil company directors, that the major foreign oil companies are 'invited' to take into consortiums as a part of the government's 'nationalisation' and 'local content' policies. These companies contribute very little in terms of investments, personnel, technology 
or other inputs, but they appear on the scene when profits are distributed (Amundsen 2014: 176). ${ }^{11}$

In Kenya, according to John Githongo (the former head of the Kenya Anti-Corruption Commission), senior officials in the Kibaki regime were linked to graft and fraud. He found strong evidence that several senior members of the government were involved in a series of fraudulent contracts with the non-existent Anglo Leasing Company, and they also actively attempted to cover up this and other fraudulent transactions once it became clear that they were the subject of investigations (Bachelard 2010: 191).

\section{Extortion}

Extortion is the use of force, threats, harassment or persisting demands by the state or its security services to extract money or other resources from individuals, groups and businesses.

One of the most glaring examples of high-level and violent extortion is the 'nationalisation' (outright seizure) of white farms in Zimbabwe and their redistribution to the members of the ruling elite. In one account, 'this extractive institution had devastating effects on the population and economy. Many white farmers fled the country, taking their agricultural expertise with them. With no plan in place to keep the planting and harvesting cycles turning, approximately 400,000 farm workers were left unemployed, and the government failed to manage the farms, leading to shortages of food such as corn and export crops such as tobacco' (Cain 2015: 2).

An example from Angola was the importer and salesman of Honda cars, whose quite profitable business was outright confiscated by a regime insider. The Honda company in Japan simply got a notification from the Ministry of Trade that another person had taken over the import licence. Although the latter was 'politically exposed', Honda accepted, and the original salesman's protests and court case led to nothing. ${ }^{12}$

11 The Norwegian state-owned oil company Statoil was involved in a case criticised by the Norwegian Auditor General and reported by Global Witness (2008): 'In Angola, StatoilHydro is in partnership with a local private oil company despite suspicions that the company's undisclosed owners may include government officials, in a country perceived to be one of the most corrupt in the world.'

12 Personal interviews, Luanda, October 2013. 
Less known and less serious is extortion in the form of ruling political parties (or coalition partners or prospective ruling parties) putting pressure on businesspeople and private companies to finance their party organisations and political campaigns. Political 'donations' can be extortion when the private businesses have reason to fear future losses of government contracts.

One example is from the Côte d'Ivoire, where the ruling party PDCI held a party congress in Abidjan in 1996, asking local private businesses to host the congress, house and feed the delegates and so on - a request that no company dared refuse. ${ }^{13}$

\section{POWER-PRESERVING POLITICAL CORRUPTION}

Power-preserving political corruption is the corrupt use of fraudulently acquired resources (but also other privately owned means and various state resources) for political support and protection purposes.

Corruption is, however, not the only power-preserving tool. There is a long list of methods of power abuse, power enhancement and preservation that are not necessarily corrupt. It should suffice to mention guns and tanks (violence), manipulation of elections (or not holding elections), harassment and intimidation of the opposition, amendments to the constitution (for instance to remove the ban on more than two presidential terms), stifling of the free press and freedom of speech, and the two methods that have become increasingly popular: (1) to target and jail opposition leaders, activists and rivals in anti-corruption drives and (2) ferocious tax collection. ${ }^{14}$ It is the corrupt use of the funds that distinguishes power-preserving political corruption from the other forms of misuse of state power.

13 Personal interviews, Abidjan, September 1996.

14 In September 2017, The Economist published the article entitled 'Beware the Taxman. Tax Authorities are the Latest Tools of Repression in Africa', describing among other cases the story of Diane Rwigara, who announced her candidacy for the presidential elections in Rwanda, and days after was disqualified for alleged tax evasion and charged with 'offences against state security', and the story from Zambia, where most of the media favoured Edgar Lungu, the president, in the election in 2016, except for a 'punchy tabloid called the Post', which the Zambia Revenue Authority shut down, saying it owed some US\$6 million in unpaid taxes. 
Corrupt power-preserving methods serve the purpose of creating a favoured group of allies and impunity through a selected allocation of tangible resources. The methods include some well-known tactics such as favouritism (the buying of friends, allies and supporters through government favours to hand-picked individuals and groups - also called nepotism, clientelism, patronage and cronyism, depending on techniques used and the characteristics of the favoured), and co-optations (the buying off of rivals and opponents, by for instance providing them with rewarding positions in state and government).

Corrupt power-preserving methods also include the fraudulent manipulation and weakening of institutions for the purpose of creating impunity for the power holders. The 'buying off' of officials of various institutions of oversight and control such as courts, auditor generals, anti-corruption agency commissioners and so on, is a widely used political corruption tool.

This selected or purpose-fit allocation of resources make the political power-holders into active bribers. The initiative is taken by the power holders, and it is clearly in their personal interest (individual and group benefit) to preserve their power positions. Furthermore, in the same way as the corrupt use of funds distinguishes power-preserving political corruption from other forms of misuse of state power, the corrupt methods of power preservation distinguish it from a democratic distribution of favours (and burdens), as the decisions are made by the few and for the benefit of the few.

\section{Favouritism and Co-Optations}

Favouritism is, crudely put, the unfair favouring of one person or group at the expense of others, for political purposes. Favouritism is partiality in the allocation of public resources, and it can be used as a tool for power enhancement and preservation. Rival politicians, military and business elites of strategic importance, influential 'families', clans and social groups sometimes 'need' to be 'bought' through favours.

Political loyalty can be bought in many ways, through a strategic distribution of government projects, infrastructures, public jobs and appointments, and public and political positions with perks. Political loyalty can also be bought with direct bribes, and 
advantages channelled to private businesses owned by friends and supporters (for example state contracts, loans, guarantees, protection, monopolies).

Favouritism and patronage are in many cases the 'glue' that holds regimes together when state institutions are weak, and in cases of violent conflict it can be central to a political settlement - formal or informal - to secure the government. Clientelist favouritism (also called patronage and cronyism) is to favour your own kin (clan, tribe, ethnic, religious or regional group) and your political supporters (friends, followers, allies and loyalists). Often, favouritism will contribute to the durability of authoritarian regimes (Zaum 2013: 1).

In Kenya, the harambees ('voluntary' contributions to community development projects) have reportedly become a tool for patronage used by politicians to garner votes, maintain loyalty of their electorate, and solidify and shape political leadership at the local level (Baskin and Mezey 2014: 57). In Angola, the so-called 'Christmas bonuses' were another form of favouritism, where 'worthy' members of the political establishment, including ruling and 'opposition' party MPs, received an annual 'bonus', paid in cash at the presidency (Amundsen 2014: 180-81).

Nepotism is a particular form of favouritism in which the office holder gives preference to his or her kinfolk and family members (wife, brothers and sisters, children, nephews, cousins, in-laws and the extended family). The preferences are basically jobs in the state apparatus or political positions in government and the ruling party, regardless of professional merit, but can also involve advancement and favours rendered to their businesses.

Nepotism is hard to detect, as decision making regarding hiring and promotions involves complex and sometimes unwritten rules and procedures, and the subjective elements that come into play when choosing among candidates can mask the abuse of power. In order to see it, one has to know the legitimate requirements for a particular position and compare this with the characteristics of candidates selected for the position.

One example is from Indonesia, where Olken (2007) found that family members of government and project officials were more likely to have found work than others, in over 600 Indonesian village road projects. He also found that family members of village 
officials were more likely than people without family ties to be employed in a higher-wage category on the project.

Co-optation is another example of favouritist treatments that can be used for political purposes. Co-optation refers to the intentional extension of benefits to potential challengers to the regime in exchange for their loyalty' (Corntassel 2007: 139). In other words, co-optation is the buying off of political rivals. Co-optations are used to build political loyalty and support from certain 'opposition' parties and politicians, and to build coalitions (Amundsen 2006: 4).

\section{Manipulation of Institutions}

By corrupt means, power holders can secure their hold by buying and manipulating public institutions of accountability and control. They can buy parliamentary majorities and favourable legislative decisions, and they can buy favourable decisions and lenient controls by various control agencies (ombudsmen, comptrollers, auditors, prosecutors). Even loyal decisions from electoral commissions and high courts have been bought.

The latter point is clear from the example of the questionable impartiality of the election commission in Bangladesh. The problem is that appointments to various positions in the commission have allegedly been made based on political considerations, bringing into question the impartiality of the commission (Amundsen 2006: 7).

Vote-buying ranges from the bribing of election officials to the bribing of voters by offering pecuniary benefits, local development projects, money, gifts and jobs. It has been defined by Brusco et al. as 'the payment by political parties of minor benefits (food, clothing, cash) to citizens in exchange for their votes' (2004: 66), and in their study on Argentina they found that in two elections these handouts significantly boosted the probability of a vote.

Vote-buying also includes the buying of parliamentary votes and majorities. One example is vote-buying in congress in Brazil. In 2005, the minority ruling Labour Party was accused of paying a monthly allowance of 30,000 Brazilian reals (12,500 US dollars) to congressmen from two allied parties in return for their votes (Amundsen 2006: 7).

The buying of legal impunity is another method of powerpreserving political corruption. Glaesera et al. (2002: 199, 213-14) argue that in many countries the operation of legal, political and 
regulatory institutions is subverted by the wealthy and the politically powerful for their own benefit, and tell the story about how the subversion of political and legal institutions brought crony capitalism to Yeltsin's Russia.

The example of the Nicaraguan pact demonstrates how an informal agreement between the leaders of the two biggest parties has secured them both a seat in the National Assembly, and thus immunity, and this has blocked investigations of corruption (Amundsen 2006: 7).

One example of the use of state resources for party campaigning and electioneering is the 'Dashain allowance' in Nepal. In 2005, the Royal Commission for Corruption Control began the prosecution of six former ministers for misusing the prime minister's relief fund to distribute some 4 million Nepalese rupees $(57,000$ US dollars) to political supporters (ibid.).

\section{IMPLICATIONS FOR RESEARCH AND ACTION}

The distinction between political and bureaucratic corruption has consequences for analysis and methodology as well as for anticorruption work. We believe that by employing the distinction we can better understand some of the reasons why the record of anti-corruption interventions has been so poor. As argued by Marquette and Peiffer, anti-corruption interventions are based on a theoretical misunderstanding of the nature of corruption. In their words, 'principal-agent theory has fallen short in providing viable solutions to the [corruption] problem' (Marquette and Peiffer 2015: 2).

\section{Measurement and Research}

The main implication of the political-bureaucratic distinction of corruption is that it makes research and analysis more precise. Instead of lumping the two together - which is done in too many studies that contribute to more confusion than clarification - the distinction opens up for more precise measures, data, and diagnostic tools. 
Bureaucratic corruption takes place at the implementation end of politics, where civil servants meet the public. Thus, opinion surveys, score cards and other direct reporting procedures can give relatively precise data of the magnitude and mechanisms of bureaucratic corruption. Good survey data outstrips all other data sources if you want to understand with accuracy and measure bureaucratic corruption, as one can directly measure people's experiences in having to pay a bribe.

However, these data collection methods cannot be used to measure political corruption. The public cannot directly observe it. And, due to the nature of the crime, there is severe underreporting; the data that police and other law enforcement agencies, NGOs and the media collect and report on are very patchy. This 'anecdotal evidence' does not come close to the true number of cases. In fact, there are no methodological tools that can directly and precisely measure political corruption.

We will therefore have to break down political corruption into its constituent components, first into extractive political corruption and power-preserving political corruption, and second into the two forms' manifestations as described above, and then measure these, directly if possible and indirectly if necessary.

We will argue that extractive political corruption cannot be assessed using the generic and indirect methods often used to assess corruption in general, like the World Bank Institute's Control of Corruption indicator and TI's Corruption Perceptions Index, ${ }^{15}$ because these are (indirectly) measuring political and bureaucratic corruption combined (or rather, the sum of opinions of those who, when asked to rank corruption in their country, have political corruption in mind and those who have bureaucratic corruption in mind). ${ }^{16}$ This is not good enough - as we have seen, there are

15 The 'control of corruption' indicator is one of six indicators of the Worldwide Governance Indicators (WGI) (http://info.worldbank.org/governance/ wgi/\#home), which covers over 200 countries, and TI's Corruption Perceptions Index (https://www.transparency.org/news/feature/corruption_perceptions_index_ 2017) covers 176 countries.

16 The WGI 'control of corruption' indicator captures 'perceptions of the extent to which public power is exercised for private gain, including both petty and grand forms of corruption, as well as 'capture' of the state by elites and private interests' (Kaufmann et al. 2010: 4). 
countries in which political corruption by far overshadows bureaucratic corruption, and vice versa.

There are some other, possibly useful, proxy indicators - for example indexes such as the World Bank Groups' Ease of Doing Business (EDB) index and the Global Financial Integrity's Illicit Financial Flows (IFF) reports. ${ }^{17}$

The EDB ranks the national regulatory environment; a higher score means it is more conducive to the starting and operation of a local firm; it indicates better, usually simpler, regulations for businesses and a stronger protection of property. If it takes a very long time to register a business this can indicate that other ('politically exposed') businesses are already 'in', being given preferential treatment and perhaps an informal monopoly. If there is a low level of legal protection of private property, this can indicate that someone is rather interested in appropriations and 'land grabs'.

The IFF measures money or capital movement from one country to another, and classifies it as illegal when the funds are illegally earned, transferred and/or utilised. This includes drug and terrorist money, money from human trafficking, trade mis-invoicing, transfer pricing and tax evasion, as well as corrupt public officials' money transfers and deposits. The problem with this index is that data on the latter (corrupt public officials' money) are combined in the index with drug and terrorist money and other 'hot money outflows', and there is no distinction made between private businesses, state bureaucrats and politicians.

Another possible proxy is to use the 'red flags' method on public procurement. The red flags are warning signals identified in the literature as associated with institutionalised corruption. Many of these are measurable, such as an extremely short submission period, single bids (which signals lack of competition and closed access), and contract performance at a price considerably higher than originally contracted. Combining these elementary risk indicators into a composite index can give a risk score that is robust over time and across countries (Tóth and Fazekas 2014: 2).

Two more possible proxies are the Political Influence Indicator, which gauges the degree of political influence on companies'

17 See: www.doingbusiness.org/rankings and www.gfintegrity.org/issue/illicitfinancial-flows. 
market success (assuming that, in a systematically corrupt environment where political favouritism drives procurement markets, a government change will make some companies 'unexpectedly' much more successful than their peers while others 'unexpectedly' lose ground), and the Political Control Indicator, which measures if the supplier or bidder has or has had political office holders among its owners and managers (assuming that political connections may be exploited to gain undue advantage in competing for government contracts) (ibid.: 2-3).

The problem with these and other indexes is that they cover only some aspects of extractive political corruption. Combined, however, and combined with other methods, they can shed much light on the issue.

Power-preserving political corruption can to some extent be assessed with the many democracy and integrity indexes. These include the Economist Intelligence Unit's (EIU's) State of Democracy Index, the World Bank Institute's Worldwide Governance Indicators (WGI), the Index of Public Integrity (IPI) and the Ibrahim Index of African Governance (IIAG). ${ }^{18}$ Again, the problem is that even when these indexes give an overall picture of the level of governance, democracy and integrity, the issue of power abuse encompasses much more than corruption for power-preservation purposes.

More useful yet are the indexes on specific government institutions such as the parliament and the judiciary, and the efficiency of 'checks and balances' (restricted government). Regarding parliaments, good, comparable, updated and publicly available statistics on parliamentary performance and levels of accountability do not exist. To our knowledge, there is only the outdated Fish and Kroenig (2009) Parliamentary Powers Index (PPI). This provides a snapshot of the state of legislative power in the world as of 2007, and it uses a panel of experts to gauge the legislature's sway over the executive, its institutional autonomy, its authority in specific areas and its institutional capacity, but the background data are not available.

18 See: https://infographics.economist.com/2017/DemocracyIndex, http://info. worldbank.org/governance/wgi/\#home, http://integrity-index.org, and http://mo. ibrahim.foundation/iiag/. 
There is, however, a useful proxy on transparency in the budget process. Since the parliament is the main institution responsible for raising and using public funds, and the main authority for checking on the government's spending of public money, this is a good indicator of parliamentary accountability (which is the opposite of being manipulated and subservient to the executive). The International Budget Partnership's Open Budget Survey ${ }^{19}$ measures how much information the government provides to the public in its budget documents ('to obtain a clear understanding of the budget and to provide a check on the executive').

Regarding judiciaries, data on the rule of law are easily available, and data on the ability of the judiciary to hold the executive to account (judiciaries' check and balances capability) can be found. There are individual country reports of quality, such as the US Department of State Human Rights Country Reports, and some comparative and longitudinal data on the rule of law such as the WGI indicator Rule of Law and the World Justice Project's Rule of Law Index. ${ }^{20}$ The Electoral Integrity Project ${ }^{21}$ measures perceptions of electoral integrity, which can indicate manipulations if the values are low.

In sum, however, most of these existing datasets cover slightly different aspects of and either narrower or broader issues than power-preserving political corruption. Again, a strategic choice and a combination of methods can nevertheless shed much light on the issue.

\section{Implications for Anti-Corruption Work}

Persson et al. (2013) argue that despite a worldwide increase in awareness of the detrimental effects of corruption and increased priority given to the fight against systemic corruption, few successes have resulted. Like Marquette and Peiffer (2015), they argue that part of the explanation as to why anti-corruption reforms fail is that they are based on the theoretical misconceptualisation of

\footnotetext{
19 See: http://survey.internationalbudget.org/.

20 See: www.state.gov/j/drl/rls/hrrpt/index.htm and http://worldjusticeproject. org/rule-of-law-index.

21 See: https://www.electoralintegrityproject.com.
} 
corruption as a principal-agent problem. This theoretic lens presupposes non-corruptible and 'principled' so-called principals, which is not necessarily the case. Too often, the principals are corrupt and not acting in the interest of the society but instead pursuing their own narrow self-interests (Persson et al. 2013: 451). This is entirely in line with our understanding of political corruption.

Khan (2016: 3) has argued that anti-corruption strategies often wrongly assume that aggregate levels of corruption can be reduced through a top-down combination of policies that improve enforcement of the rule of law and changes to the expected returns of corruption (for example, through bureaucratic pay increases, greater transparency or harsher punishments). These strategies have generally delivered modest reductions in corruption in contexts of entrenched political corruption, which Khan calls a 'configuration of social power [that] does not support the enforcement of generalized rule-following behaviour' (ibid.: 3).

Political corruption cannot be tackled by a technical and/or technical/bureaucratic approach alone, by capacity-building interventions and technical support, and it cannot be treated only as another problem of market regulation or good governance. Political corruption is when the ruling elite/government is corrupt, when individuals with political power are corrupt and therefore - of course - lack the political will to address corruption. This means that the country's policies and priorities as well as individual politicians' actions will directly contradict and/or annihilate most anti-corruption efforts.

Sometimes, there will be political resistance to anti-corruption, as corrupt politicians will defend their vital interests vehemently and sometimes even violently. At other times, corrupt politicians will pick and choose what anti-corruption measures to implement, and these will typically not be the ones that will reduce their own opportunities for extraction and power preservation, but rather those that will increase government legitimacy and efficiency, and preferably, simultaneously reduce the influence of political rivals and opponents.

Political corruption calls for political solutions. Deepened democracy is to a large extent a question of the institutional capability of public and private institutions to control and withstand the pressures for elite extraction and elite reinvestment in power. 
The solution to the problems lies particularly in the institutionalisation of public control mechanisms and in the 'ring-fencing' of informal practices. That is, the solution will have to include institutional checks and balances, free and fair elections, human rights, and horizontal and vertical accountability mechanisms.

\section{REFERENCES}

Amundsen, I. (2006), 'Political corruption', Bergen: Chr. Michelsen Institute, U4 Issue 6:2006.

Amundsen, I. (2014), 'Drowning in oil. Angola's institutions and the "resource curse", Journal of Comparative Politics, 46(2): 169-89.

Andvig, J.C., O-H. Fjeldstad, with I. Amundsen, T. Sissener and T. Søreide (2001), 'Corruption: a review of contemporary research', Bergen: Chr. Michelsen Institute, CMI Report R 2001:7.

Argandoña, A. (2017), 'The changing face of corruption in the Asia Pacific', in M. dela Rama and C. Rowley, The Changing Face of Corruption in the Asia Pacific, Oxford/UK: Elsevier Ltd.

Bachelard, J.Y. (2010), 'The Anglo-Leasing corruption scandal in Kenya: the politics of international and domestic pressures and counter-pressures', Review of African Political Economy, 37(124): 187-200.

Baskin, M. and M.L. Mezey (eds) (2014), Distributive Politics in Developing Countries: Almost Pork, London: Lexington Books.

Booth, D. and F. Golooba-Mutebi (2012), 'Developmental patrimonialism? The case of Rwanda', African Affairs, 111(444): 379-403.

Brusco, V., M. Nazareno and S.C. Stokes (2004), 'Vote buying in Argentina', Latin American Research Review, 39(2): 66-88.

Cain, G. (2015), 'Bad governance in Zimbabwe and its negative consequences', The Downtown Review, 2(1).

Cohen, N. (2007), 'The politics of sleaze', The Guardian, 16 November 2003.

Corntassel, J. (2007), 'Partnership in action? Indigenous political mobilization and co-optation during the first UN indigenous decade (1995-2004)', Human Rights Quarterly, 29(1): 137-66.

della Porta, D. and A. Vannucci (1999), Corrupt Exchanges: Actors, Resources, and Mechanisms of Political Corruption, New York: Walter de Gruyter Inc.

Demir, F. (2010), 'A political economy analysis of the Turkish military's split personality: the patriarchal master or crony capitalist?' in T. Cetin and F. Yilmaz (eds), Understanding the Process of Economic Change in Turkey: An Institutional Approach, New York: Nova Science Publishers.

Easton, D. (1965), A Framework for Political Analysis, Englewood Cliffs: Prentice-Hall.

Encyclopædia Britannica: Public Administration, https://www.britannica.com/ topic/public-administration (accessed 17 August 2018).

Fish, M.S. and M. Kroenig (2009), The Handbook of National Legislatures: A Global Survey, New York: Cambridge University Press. 
Fraud Magazine (2018), '5 most scandalous fraud cases in 2018', Fraud Magazine, November 2018, https://www.fraud-magazine.com/2018Top5 Frauds/ (accessed 15 April 2019).

Frederickson, H.G. (ed.) (2015), Ethics and Public Administration, New York: Routledge.

Glaesera, E., J. Scheinkmanb and A. Shleifera (2002), 'The injustice of inequality', Journal of Monetary Economics, 50 (2003): 199-222.

Global Witness (2008), StatoilHydro's Libyan Corruption Scandal Shows Need For Oil Industry Disclosure Laws, London: Global Witness, Report November 2008 .

Heidenheimer, A.J. and M. Johnston (eds) (2002), Political Corruption: Concepts and Contexts, 3rd edn, New Brunswick/NJ and London: Transaction Publishers.

Hessami, Z. (2014), 'Political corruption, public procurement, and budget composition: theory and evidence from OECD countries', European Journal of Political Economy, 34: 372-89.

Heywood, P.M. (2015), Routledge Handbook of Political Corruption, London: Routledge.

Hjellum, T. (2007), Politisk korrupsjon som demokratisk problem, Oslo: Cappelen Forlag.

Huntington, S.P. (1968), Political Order in Changing Societies, New Haven, Conn.: Yale University Press.

Johnston, M. (ed.) (2011), Public Sector Corruption (4 vols), Thousand Oaks/CA: SAGE Publications Ltd.

Kaufmann, D., A. Kraay and M. Mastruzzi (2010), The Worldwide Governance Indicators Methodology and Analytical Issues, Washington: World Bank (World Bank Policy Research Working Paper 5430).

Khan, M. (2016), 'Corruption Spotlight', London: Department of Economics, SOAS, University of London, Background Note for the 2017 World Development Report.

Lambsdorff, J.G. (2007), The Methodology of the Corruption Perceptions Index 2007, Berlin: Transparency International, www.stt.lt/documents/soc_tyrimai/ KSI_methodology_2007.pdf (accessed 29 March 2017).

Loftis, M.W. (2014), 'Deliberate indiscretion? How political corruption encourages discretionary policy making', Comparative Political Studies, 48(6): 728-58.

Marquette, H. and C. Peiffer (2015), Corruption and Collective Action, Bergen and Birmingham: U4 Anti-Corruption Resource Centre and The Developmental Leadership Program (DLP), Research Paper 2, https:/www.u4.no/ publications/corruption-and-collective-action.pdf (accessed 17 August 2018).

Moody-Stuart, G. (1997), Grand Corruption: How Business Bribes Damage Developing Countries, Oxford: WorldView.

Nattrass, N. (2014), 'A South African variety of capitalism?', New Political Economy, 19(1): 56-78.

Nye, J.S. (1967), 'Corruption and political development: a cost-benefit analysis', American Political Science Review, 61(2): 417-27. 
Olken, B.A. (2007), 'Monitoring corruption: evidence from a field experiment in Indonesia', Journal of Political Economy, 115(2): 200-49.

Persson, A., B. Rothstein and J. Teorell (2013), 'Why anticorruption reforms fail - systemic corruption as a collective action problem', Governance, 26(3): 449-71.

Tangri, A. and A.M. Mwenda (2013), The Politics of Elite Corruption in Africa: Uganda in Comparative African Perspective, Oxon/UK: Routledge.

The Economist (2017), 'Beware the taxman: tax authorities are the latest tools of repression in Africa', 30 September 2017, https://www.economist. com/middle-east-and-africa/2017/09/30/tax-authorities-are-the-latest-tools-ofrepression-in-africa (accessed 21 August 2018).

The Guardian (2015), 'Malaysian taskforce investigates allegations $\$ 700 \mathrm{~m}$ paid to PM Najib', 6 July 2015, https://www.theguardian.com/world/2015/jul/06/ malaysian-task-force-investigates-allegations-700m-paid-to-pm-najib (accessed 15 April 2019).

TI (2004), Global Corruption Report (Special Focus Political Corruption), London/Sterling VA: Pluto Press, Transparency International, http://www. transparency.org/research/gcr/gcr_political_corruption (accessed 28 March 2017).

TI (2006), Global Corruption Report 2006, Berlin: Transparency International.

Tóth, I.J. and M. Fazekas (2014), 'New ways to measure institutionalised grand corruption in public procurement', U4 Brief 2014:9, Bergen: U4 (Anti-Corruption Resource Centre).

V-Dem Institute (2016), 'The role of legislative powers for executive corruption', Stockholm: V-Dem Institute, Policy Brief No. 3, 13 January 2016.

Villoria, M., G.G. Van Ryzin and C.F. Lavena (2013), 'Social and political consequences of administrative corruption: a study of public perceptions in Spain', Public Administration Review, 73: 85-94.

World Bank (1997), Helping Countries Combat Corruption: The Role of the World Bank, Report, Washington: World Bank.

Zaum, D. (2013), Political Economies of Corruption in Fragile and ConflictAffected States: Nuancing the Picture, U4 Brief 2013:4, Bergen: U4 (U4 Anti-Corruption Resource Centre). 